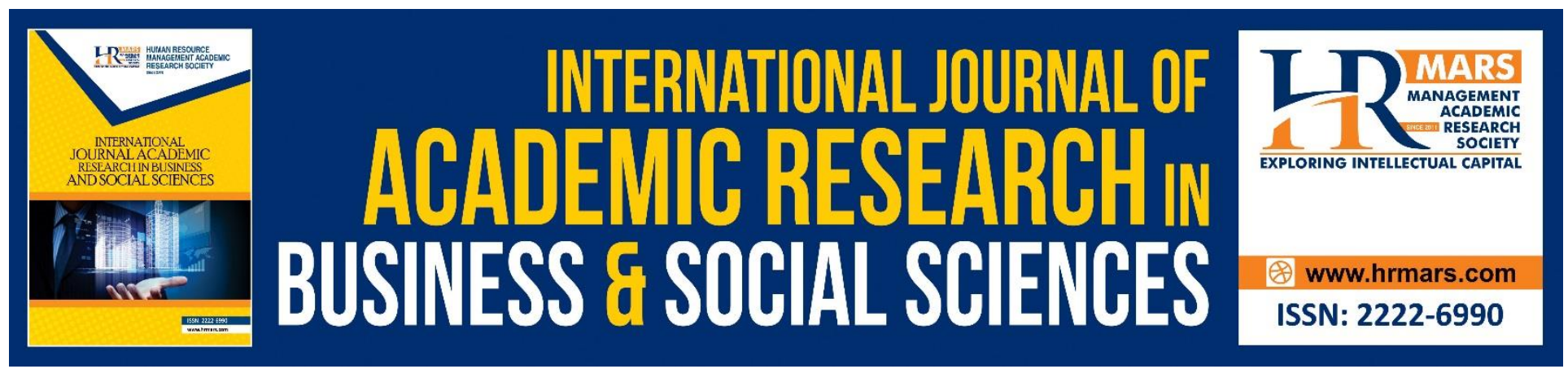

\title{
Effect of Work Motivation and Supervision on Employee's Performance: The Role of Education Level as Moderating Variable (Case Study on University of Muhammadiyah in Aceh)
}

Zikrillah, Nasir, Sulaiman

To Link this Article: http://dx.doi.org/10.6007/IJARBSS/v10-i9/7834

DOI:10.6007/IJARBSS/v10-i9/7834

Received: 04 June 2020, Revised: 08 July 2020, Accepted: 18 August 2020

Published Online: 29 September 2020

In-Text Citation: (Zikrillah, Nasir, \& Sulaiman, 2020)

To Cite this Article: Zikrillah, Nasir, \& Sulaiman. (2020). Effect of Work Motivation and Supervision on Employee's Performance: The Role of Education Level as Moderating Variable (Case Study on University of Muhammadiyah in Aceh). International Journal of Academic Research in Business and Social Sciences. 10(9), 572-588.

\section{Copyright: (c) 2020 The Author(s)}

Published by Human Resource Management Academic Research Society (www.hrmars.com)

This article is published under the Creative Commons Attribution (CC BY 4.0) license. Anyone may reproduce, distribute, translate and create derivative works of this article (for both commercial and non-commercial purposes), subject to full attribution to the original publication and authors. The full terms of this license may be seen at: http://creativecommons.org/licences/by/4.0/legalcode

Vol. 10, No. 9, 2020, Pg. 572 - 588

Full Terms \& Conditions of access and use can be found at http://hrmars.com/index.php/pages/detail/publication-ethics 


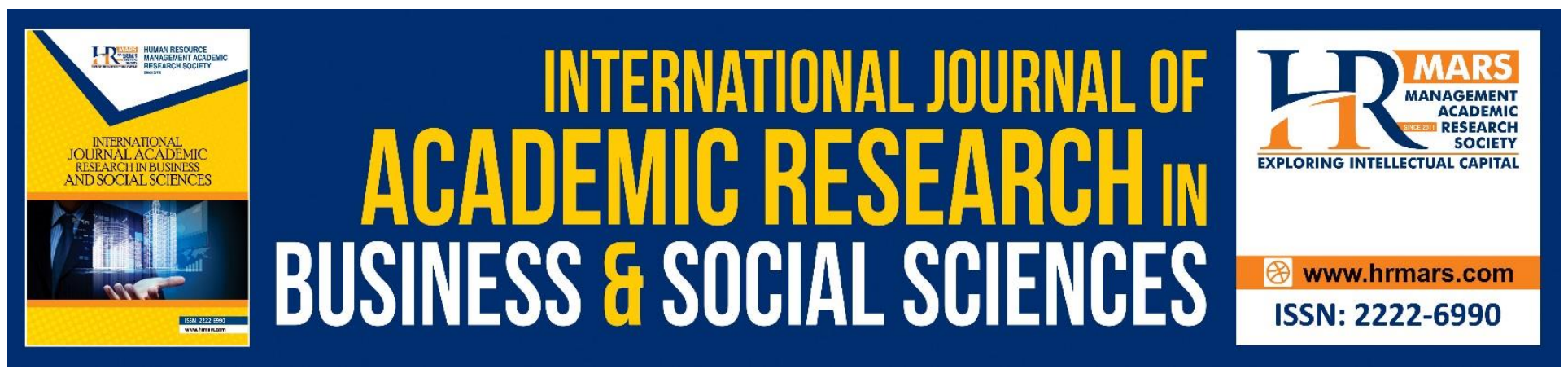

\title{
Effect of Work Motivation and Supervision on Employee's Performance: The Role of Education Level as Moderating Variable (Case Study on University of Muhammadiyah in Aceh)
}

\author{
Zikrillah $^{1}$, Nasir$^{2}$, Sulaiman ${ }^{3}$ \\ 1) Master of Management Post-Graduate Study of Syiah Kuala University Banda Aceh, ${ }^{2,3)}$ Faculty of \\ Economic and Business, University of Syiah Kuala \\ Email: elman_ali@unsyiah.ac.id
}

\begin{abstract}
This study aims to analyze the effect of work motivation and supervision on employee performance and to analyze the existence of education level as a moderating variable in the functional relationship between these variables. The study utilizes a census to involve all of 123 employees as respondents at Muhammadiyah's University in Aceh using a census. Data is collected by a questionnaire survey and analyzed by structural equation modeling (SEM) and moderated regression analysis (MRA). The study finds that work motivation, supervision and education level have a positive and significant effect on employee performance. The existence of the level of education moderates the effect of work motivation on employee performance. On the other hand, the level of education does not moderate the effect of supervision on employee performance.
\end{abstract}

Keywords: Employee's Performance, Education Level, Work Motivation, Supervision.

\section{Introduction}

There have been many previous studies that explain the factors that affect employee performance. These factors include psychological empowerment, competence and meaningful work (Degago, 2014); organizational culture (Uddin et al., 2013); direct compensation (Ahmed \& Ahmed, 2014); work motivation (Chong \& Van, 2013; \& Shahzadi et al., 2014); job satisfaction (Chong \& Van, 2013; Fadlallh, 2014; Luthans, 2015; Robbins, 2012; and Chong \& Dung, 2013); work environment (Srivastava, 2008); and leadership (Bello, 2014), and transformational leadership (Ali and Tang, 2016; and Mohiuddin, 2017).

In further research, there are also educational factors (González et., Al. 2016); and supervision (Situmeang, 2017; Syamsidar \& Hasyim, 2018) which can also affect performance.

However, there is very few pay attention to this factor (education), especially if it acts as a moderator. The role of moderating education level to intervene the influence of work motivation on 
employee performance is supported by a number of studies. As with research (Capelleras et al., 2016) which found that the level of education intervenes in the influence of work motivation and personal supervision on employee performance. On a macro scale, the level of education also moderates the effect of employee status (employed or not working) on the emergence of inspiration for job search. Lee \& Hallak's (2018) research also proves that education level moderates the influence of motivation on employee performance. This finding is also supported by the results of Chang's (2019) study that the level of education not only moderates the effect of work motivation, but also moderates the effect of work motivation on employee performance; for example, at University of Muhammadyah in Aceh as private institution.

Universitas Muhammadiyah Aceh has permanent and non-permanent staffs that consist of academics and administrative. They are distributed from the Rectorate Bureau to the faculties and other non-structural institutions. In terms of permanent employees, they are who already have a letter of appointment as employees, where the decree contains information about the rights and obligations of the employee and the work unit has been determined. Meanwhile, non-permanent employees are employees who already have a Decree and information on the rights and obligations of employees are not the same as permanent employees, in terms of the amount of salaries and allowances and working hours, and it is based upon their performance.

The quality of an employee's performance can be seen from their work history, experience and achievements. On the other hand, discipline is a major problem for employees, especially the absence of sanctions against this disciplinary behavior due to limited supervision. When employees are motivated from competencies based on their educational background, the organization needs to supervise every job whether it is well done to ensure the suitability of work procedures and goals of the organization.

However, due to very little attention from the previous studies having pay attention for this matter (educational background) as a mediator factor; therefore, it seems still hazy for academics and practitioners that appears the gab of understanding.

Based on the above viewpoint, it is necessary to conduct further research to eliminate the gap due to the insufficient understanding. Thus, objective of this study is to investigate relationships between work motivation, supervision and employee performance that are moderated by educational background. Therefore, it may result a contribution to academics and practitioners whereas the role of educational background as a moderator between the relationships.

\section{Literature Review}

\section{Employee Performance}

Performance is a reflection of records relating to the final results an employee can achieve for the work within a certain period (Bernardin \& Russel, 2013). This concept is consistent with Robbins (2012: 212) that Employee performance reflects the work achievements that an employee can produce within a certain period compared to predetermined standards or targets and criteria. This means that work performance is generally related to the job or type of work performed by a person with reference to the ability and availability of the work as well as the work environment that it can be measured. 
INTERNATIONAL JOURNAL OF ACADEMIC RESEARCH IN BUSINESS AND SOCIAL SCIENCES

Vol. 10, No. 9, 2020, E-ISSN: 2222-6990 @ 2020 HRMARS

Indicators of measuring employee performance refer to Notes on the final results obtained after a job or activity is conducted within a certain period (Bernardin \& Russel, 2013) including quality, quantity, timeliness, independence, and commitment.

\section{Motivation}

Hasibuan (2012: 95) explicitly states that work motivation is identical to providing the driving force that creates the desire to work in order to meet the needs that will be met. Furthermore, Siagian (2016: 102) states that motivation is basically the driving force for someone to contribute to achieving organizational goals.

The above definition is also in line with Fathoni (2016: 132) who mention that work motivation can be seen as a process that moves people to want to do something as expected by the motivator or that activates them.

The willingness of a subordinate to direct his wills, expertise and skills at work (Segal, 2010: 26). According Segal (2010), work motivation can be measured by strongly desire to do work, the desire to improve work performance, the desire to carry out duties and responsibilities properly, always strive to realize job targets, there is an attempt to be successful even if having failed in a certain task, persistence and persistence in completing difficult tasks, and not easily bored and always enjoy routine work.

\section{Supervision}

Handoko (2011: 359) justifies that supervision is a process to ensure that organizational and management goals can be achieved. Purpose of conducting supervision) is to help members of the organization overcome the various weaknesses that exist in themselves and provide guidance so that the negative behavior modification occurs (Siagian, 2016: 41).

Moreover, Bangun (2012) defines supervision is a process for assessing the suitability of the work of organizational members in various fields and various management actions with predetermined programs. According to Bangun (2012), there have been five indicators to measure supervision; namely, every employee is inseparable from supervision, there is a clear standard of work for each employee, there is an assessment of the work, there is an evaluation of work performance, there are procedures that allow work improvements.

\section{Educational Level}

Education is a long-term process that uses systematic and organized procedures, in which the managerial workforce learns conceptual and theoretical knowledge for general purpose purposes (Mangkunegara, 2013: 50).

Hasbullah (2013: 1) states that education is often interpreted as a human effort to foster his personality according to cultural and community values. He further states that education is an effort carried out by a person or group of other people in order to become an adult or to achieve a higher level of life or livelihood in a mental sense.

The high level of education of an employee will affect his ability to achieve optimal performance, as expressed by Notoatmodjo (2013: 28) who also states that education within an organization is a process of developing capabilities towards the desired direction of the organization concerned. 
INTERNATIONAL JOURNAL OF ACADEMIC RESEARCH IN BUSINESS AND SOCIAL SCIENCES Vol. 10, No. 9, 2020, E-ISSN: 2222-6990 @ 2020 HRMARS

It can be concluded that organizational support is how companies or organizations value employee contributions to the progress of the company (valuation of employees contribution) or the organization and company attention to their lives (care about employees well-being).

Indicator to measure level of education refer to Notoatmodjo (2013) consisted of graduate and post graduate levels.

The following research frameworks are developed that can illustrate the effect of work motivation and supervision on employee performance, in which educational level acts as moderating variable influencing.

\section{Effect of work motivation on employee performance}

The willingness of a person to work is usually driven by the desire to get something he wants to fulfill. Everyone hopes that the activities carried out can make it in a more satisfying condition as a result of fulfilling needs (As'ad, 2013: 215). This can be interpreted explicitly that in every human being there is a need which implies that the efforts or efforts they make are oriented towards meeting these needs. Efforts to meet these needs are a driving factor in carrying out work. There is a relationship between work motivation and performance, as stated by Mangkuprawira (2013: 117) that the factors that influence employee performance are relatively complex, including intrinsic factors or factors that come from within the employee, including work motivation. Apart from coming from within oneself, the strength of a person's work motivation can also come from the environment. The values and norms adopted by the social environment in which a person works can encourage work motivation and in turn have an impact on performance (Fathoni, 2016: 132).

The important role of work motivation in encouraging performance formation is also stated by Uno (2007: 71) that work motivation is an important determinant of an employee's performance. The strength of motivation in a person is determined by how much intensity of motivation he feels, and the performance achievements or work achievements that he can achieve can be used as a reflection of that person's work motivation (Fathoni, 2016: 132)

Thus, the following hypotheses can be proposed:

$\mathrm{H}_{1}$ : Work motivation has a positive influence on employee performance.

\section{Effect of supervision on employee's performance}

In order to improve the performance of educational institution, supervision is required. This supervision is intended to ensure that activities conducted by education sector personnel can run properly. The importance of supervision to achieve the performance of both organizational and individual has been proven by a number of researchers. As the research of Averus and Pitono (2018), it proves that supervision has a positive and significant effect on employee performance in providing services to the community. Research by Situmeang (2017) and Syamsidar \& Hasyim (2018) also provide the similar finding, where supervision has a positive impact on employee performance.

According to the above point of view, it can be derived hypothesis as follows:

$\mathrm{H}_{2}$ : Supervision has a positive influence on employee performance.

The role of moderating education level on the relationship between motivation and employee performance

The influence of work motivation on employee performance can be intervened by the presence of other variables both related to internal and external factors of the employees 
themselves. Like the level of education; even though, an employee has a relatively high work motivation, without adequate education, it will be difficult to achieve performance. Especially for employees who work in universities. Their academic abilities really determine the smoothness of their duties; especially, when they conduct the learning process.

The role of moderating education level to intervene the influence of work motivation on employee performance is supported by a number of studies. As well as research by Orpen (1994) which found that the level of education intervenes the influence of work motivation and personal control on employee performance. On a macro scale, the level of education also moderates the effect of employee status (working or not working) on the emergence of job search inspiration (Capelleras et al., 2016). Research by Lee \& Hallak (2018) in their study of food service companies also proved that education level moderates the effect of work motivation on employee performance. This finding is also supported by the results of Chang's (2019) study of company performance, that the level of education moderates the effect of work motivation on employee performance.

Based upon the above justification, the next study hypothesis can be presented as follows: $\mathrm{H}_{3}$ : The level of education moderates the effect of work motivation on employee performance.

The role of moderating education level on the relationship between supervision and employee performance

The effect of supervision on employee performance is also inseparable from the level of education of the employee concerned. Although supervision is intended to improve employee performance at work, the effectiveness of the supervision in realizing the objectives (i.e. employee performance) is highly dependent on the level of their education. The level of education is an internal employee factor that contributes to work ability, attitudes at work and ultimately also affects the achievement of their work results.

The role of the level of education in moderating the effect of supervision on employee performance has been supported by a number of previous researchers. Research by Sargent \& Terry (1998) on the effect of job supervision on employee performance proves that an employee's education level affects the impact of supervision on performance. Moser \& Galais (2007) research also provides the same conclusion that the level of education moderates the effect of supervision on employee performance. Other studies conducted by Schjoedt \& Sangboon (2015), Sihag \& Rijsdijk (2018) and Remus et al. (2020) also concluded that the level of education affects the impact of supervision on employee performance.

Therefore, it can propose hypothesis:

$\mathrm{H}_{4}$ : The level of education moderates the effect of supervision on employee performance.

\section{Theoretical Framework of Study}

The relationship between endogenous variables and exogenous variables and the existence of educational level as a moderating variable in human resource studies, is not only supported by a theoretical basis but also strengthened by previous studies as previously explained. Therefore, the paradigm or relationship between concepts (variables) in this study can be described in the following figure: 


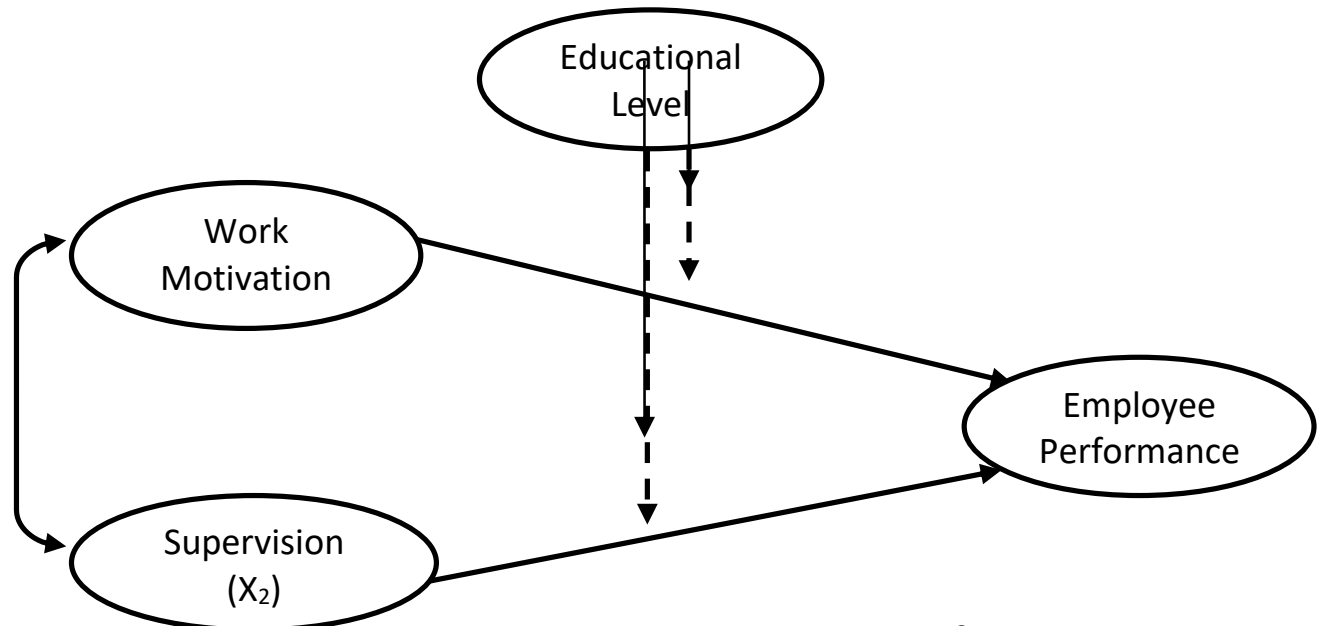

Figure 1. Theoretical Framework of This Study

\section{Research Method}

\section{Research location, population and sample}

The population in this study is 126 employees of University of Muhammadiyah (Unmuha) in Aceh Province. All members of the population are used as research samples so that this study was a population study using the census method.

\section{Data Analysis}

The object of research is related to the relationship between the performance of college employees with work motivation, supervision and employee education level. In this case, the level of education is also positioned as a moderating variable between employee performance and work motivation and supervision. Primary data is utilized by distributing questionnaire that is circulated to college employees. Furthermore, the data are analyzed using statistical tools of structural equation modeling (SEM) and moderated regression analysis (MRA) as suggested by Hair et al. (2013).

\section{Research Finding and Discussion}

\section{Structural Equation Modeling (SEM): Step-One Approach with Measurement Model}

According to the study conceptual framework, the endogenous variable in the study is employee performance. Furthermore, the exogenous variables consist of work motivation and supervision. As previously explained, the measure of goodness of fit in SEM uses several measurements consisting of X2 or chi-square statistics, GFI (Goodness of Fit Index), AGFI (Adjusted Goodness of Fit Index), CMIN / DF, namely minimum sample disrepancy function divided by degree of freedom, TLI (Tucker Lewis Index) and CFI (Comparative Fit Index) based upon argumented by Hair et al. (2013). 
INTERNATIONAL JOURNAL OF ACADEMIC RESEARCH IN BUSINESS AND SOCIAL SCIENCES Vol. 10, No. 9, 2020, E-ISSN: 2222-6990 @ 2020 HRMARS

The final results of the measurement model can be seen in the following figure:

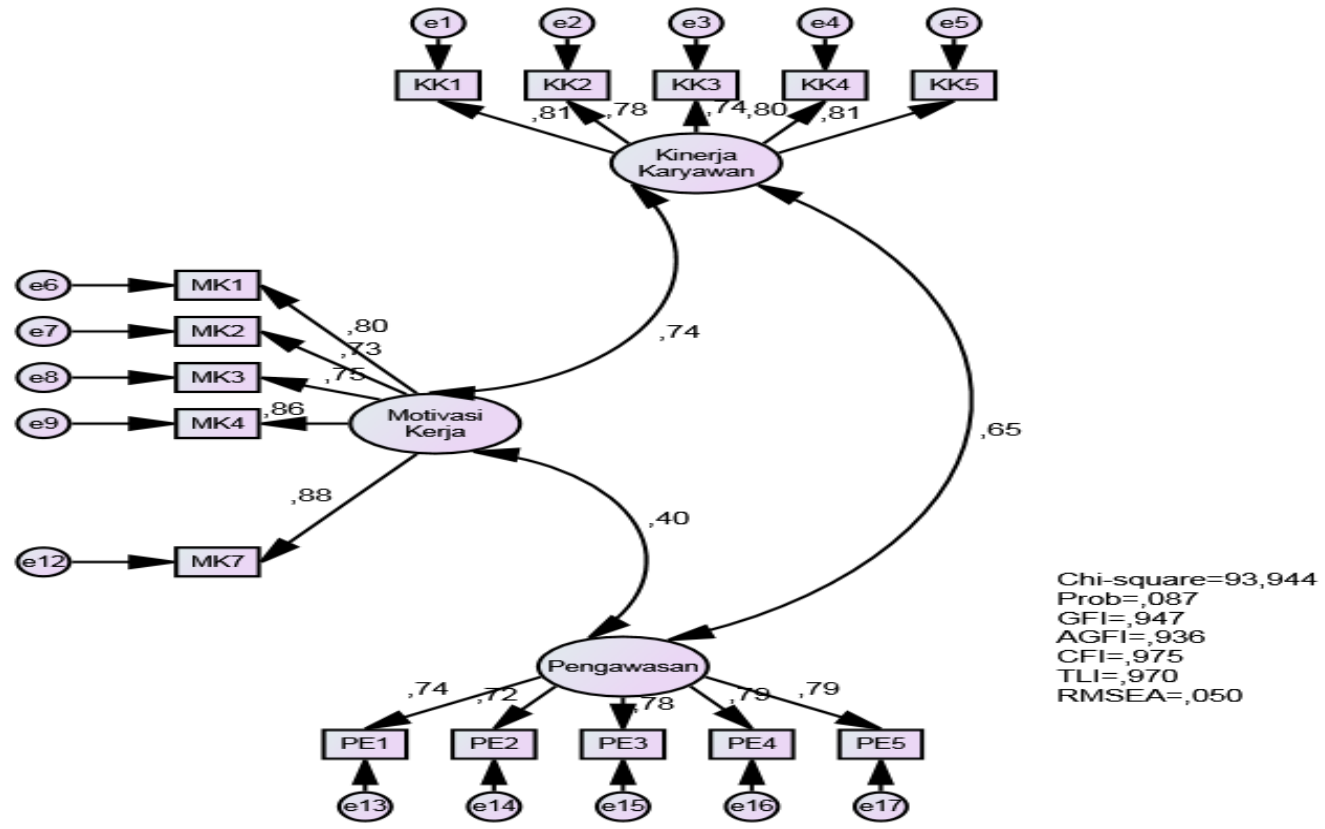

Figure 2. Measurement Model

The results of the analysis above indicate that the value of Chi-square the $X^{2}$ value counted at 93.944. While the value of $X^{2}$ table at $d f=87$ is 109.773 , which is greater than the calculated $X^{2}$ value. In other words, the value of $X^{2}<X^{2}$ tab $(93.944<109.773)$. This means that the calculated $X^{2}$ statistical value has met the predetermined criteria, so that the model is declared goodness fit. The probability or $p$-value of the measurement model results in this second stage of 0.087 has also met the predetermined criteria, which is above 0.05 . This means that seen from the p-value, the results of the measurement model have met the goodness of fit index requirements. Furthermore, based on the criteria, the GFI value has also met the requirements, which is 0.947 , which is greater than the required value of 0.90 . Likewise, the AGFI value of 0.936 is also greater than 0.90 (Hair et al., 2013).

Based on the description above, it is clear that the results of measurement model testing indicate that all the criteria have been met; therefor, the next step can be continued to the full structural equation model.

\section{Structural Equation Modeling (SEM): Step-Two Approach with Full-SEM}

This approach emphasizes on testing the theoretical model or framework of this research (see Figure 1 and the hypotheses previously described).

The final output shows that the structural equation model is fit and satisfactory for sample data with $\mathrm{x}^{2}=93.944$ at $\mathrm{p}<0.001 ; \mathrm{GFI}=0.947, \mathrm{AGFI}=0.936, \mathrm{CFI}=0.975$ and $\mathrm{TLI}=0.970, \mathrm{RMSEA}=$ 0.050 . This output also shows that all loading factors in the model are significant at $p<.001$. As explained earlier, goodness-of-fit statistics (i.e. $x^{2}$ ) must display $p>.05$ to get a good and fit model.

A clearer picture of this structural equation model can be displayed as follows: 


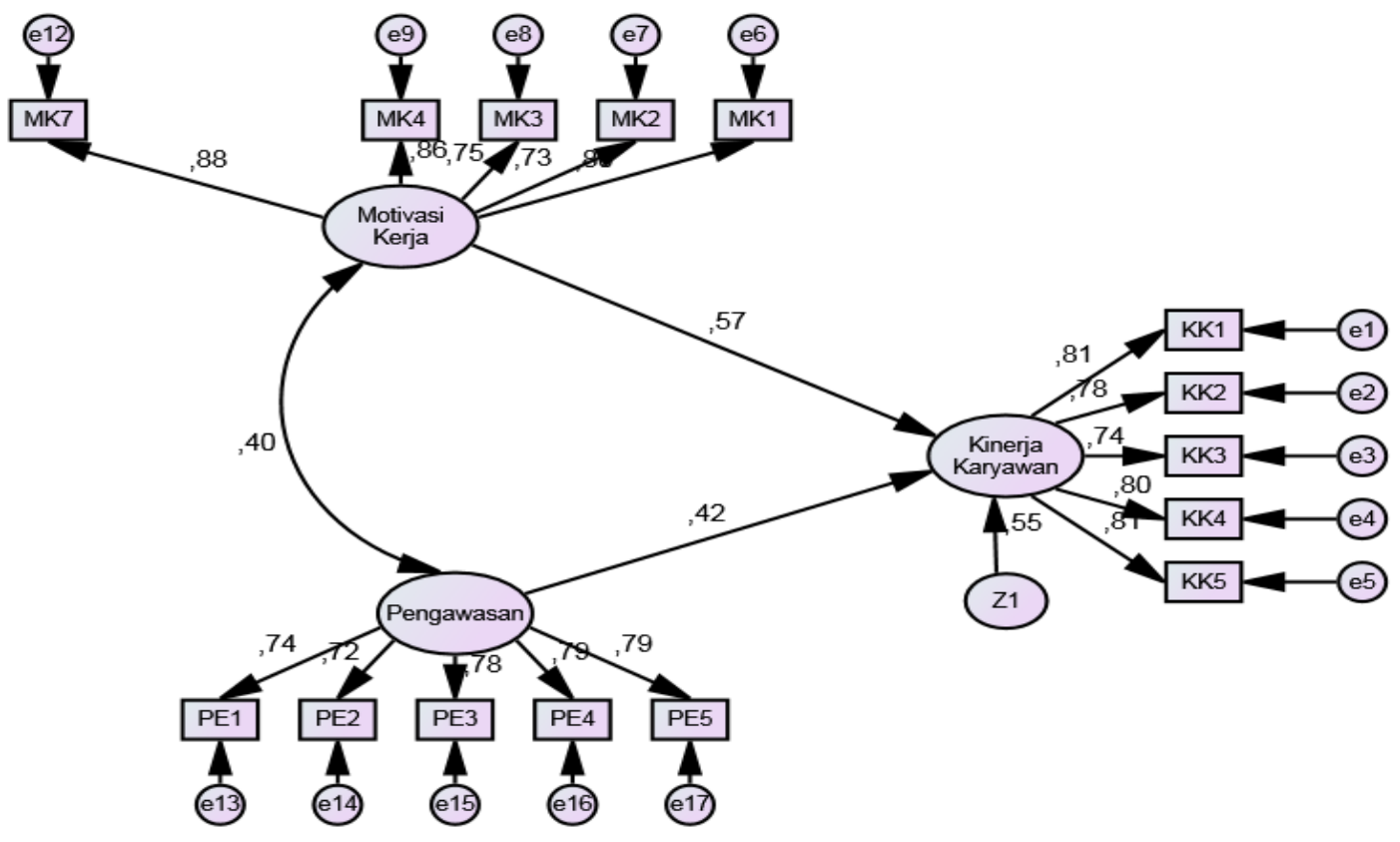

Figure 3. Full Structure Equation Modeling

The picture above not only shows the value of the path coefficient (Standardized Regression Weights) of each exogenous latent variable against the endogenous latent variable, but also shows the loading factor value of each indicator (manifest variable) on the latent variable.

\section{Direct Hypothesis Testing}

The next step is testing the hypothesis based on the critical ratio $(C R)$ and the probability $(P)$. the results of processing must be a value that is referenced, namely $C R>1.96$ with $P<0.05$.

Furthermore, the path coefficient of each exogenous construct (work motivation and supervision) to the endogenous construct (employee performance) is shown in the table below.

Table 1: Relationship among Constructions

\begin{tabular}{|lll|llll|}
\hline & & & Estimate & C.R. & P & Label \\
\hline Employee_Performance & $<---$ & Work_Motivation & .569 & 6.606 & $* * *$ & par_3 \\
Employee_Performance & $<---$ & Supervision & .423 & 5.014 & $* * *$ & par_5 \\
\hline
\end{tabular}

Source: Output of Data Analysis (2020)

The results from the above table show that the criteria value of C.R. and the $P$ value that meets the requirements is only the variable of work motivation for employee performance (C.R. = 6.606 and $P=0.000$ ) and supervision with employee performance (C.R. $=5.014$ and $P=0.000)$.

Work motivation has a positive and significant effect on employee performance at the Muhamadiyah University Aceh, indicated by the estimated coefficient value of 0.560 and the $p$-value of $0.000(<0.05)$. The higher the work motivation, the higher the performance of the university employees will be. Conversely, a decrease in work motivation can significantly reduce employee performance. The existence of a positive and significant effect of work motivation on employee 
INTERNATIONAL JOURNAL OF ACADEMIC RESEARCH IN BUSINESS AND SOCIAL SCIENCES Vol. 10, No. 9, 2020, E-ISSN: 2222-6990 @ 2020 HRMARS

performance indicates that the drive in them to do work has an impact on the work they get. So that when their work motivation increases, the results of their work will also increase. Conversely, a decrease in work motivation has a negative impact on the work they get. This finding supports the hypothesis $1\left(\mathrm{H}_{1}\right)$; in other words, $\mathrm{H}_{1}$ cannot be rejected.

This finding support the research results of Omollo \& Oloko (2015) and Muogbo (2013) which concluded that there is a positive and significant relationship between work motivation and employee performance. The better the work motivation of an employee, the better the performance of the employee concerned. These results are also consistent with the findings of Cetin's (2013) study on the hotel business and empirical research conducted by Renah \& Setyadi (2014) on government agency employees who also found that work motivation has a positive and significant effect on employee performance.

Supervision also has a positive and significant impact on the employee performance of Muhamadiyah University in Aceh, indicated by the estimated coefficient of 0.423 with a $p$-value of $0.000(<0.05)$. Increasing the intensity of supervision has an impact on improving employee performance.. This is because supervision is basically intended to ensure the implementation of employee work properly. When there are errors in work, supervision has the role of evaluating and correcting these errors so that they can be corrected.

The result presents that there is an existence of a positive and significant effect of supervision on employee performance, whereas the finding indicate to support hypothesis $2\left(\mathrm{H}_{2}\right)$. This is consistent with the findings of previous studies conducted by Situmeang (2017) and Syamsidar \& Hasyim (2018) also provide the same evidence, where supervision has a positive impact on employee performance. These findings also support the research findings of Averus and Pitono (2018) which also concluded that supervision has a positive and significant effect on employee performance.

\section{Moderating Effect Testing}

Moderated Regression Analysis (MRA) is employed to test the hypothesis of educational level as moderator among the direct relationships having been addressed in the previous section.

The following table presents the results of MRA that explains the role of educational level among relationships of work motivation, supervision, and employee performance. 
INTERNATIONAL JOURNAL OF ACADEMIC RESEARCH IN BUSINESS AND SOCIAL SCIENCES Vol. 10, No. 9, 2020, E-ISSN: 2222-6990 @ 2020 HRMARS

Table 2. Moderated Regression Analysis Results

\begin{tabular}{|c|c|c|c|c|c|c|}
\hline & \multicolumn{2}{|c|}{ Model 1} & \multicolumn{2}{|c|}{ Model 2} & \multicolumn{2}{|c|}{ Model 3} \\
\hline & $\begin{array}{c}\text { Estimate } \\
\mathrm{d} \\
\text { coefficie } \\
\mathrm{nt}\end{array}$ & $p$-value & $\begin{array}{l}\text { Estimated } \\
\text { Coefficient }\end{array}$ & $p$-value & $\begin{array}{c}\text { Estimate } \\
\text { d } \\
\text { Coefficie } \\
\text { nt }\end{array}$ & $\mathrm{p}$-value \\
\hline (constant) & $\begin{array}{c}-1,299 \\
{[-4,025]}\end{array}$ & 0,000 & $\begin{array}{c}-5,168 \\
{[-4,275]}\end{array}$ & 0,000 & $\begin{array}{c}-1,593 \\
{[-1,940]}\end{array}$ & 0,055 \\
\hline $\begin{array}{l}\text { Work } \\
\text { Motivation } \\
\text { (MK) }\end{array}$ & $\begin{array}{c}0,740 \\
{[8,427]}\end{array}$ & 0,000 & $\begin{array}{c}0,844 \\
{[9,376]}\end{array}$ & 0,000 & $\begin{array}{c}0,733 \\
{[8,135]}\end{array}$ & 0,000 \\
\hline $\begin{array}{l}\text { Supervision } \\
\text { (PE) }\end{array}$ & $\begin{array}{c}0,388 \\
{[6,058]}\end{array}$ & 0,000 & $\begin{array}{c}0,347 \\
{[5,530]}\end{array}$ & 0,000 & $\begin{array}{c}0,399 \\
{[5,676]}\end{array}$ & 0,000 \\
\hline $\begin{array}{l}\text { Educational } \\
\text { Level (PDK) }\end{array}$ & $\begin{array}{c}0,572 \\
{[8,017]}\end{array}$ & 0,000 & $\begin{array}{c}4,206 \\
{[3,824]}\end{array}$ & 0,000 & $\begin{array}{c}0,852 \\
{[1,179]}\end{array}$ & 0,241 \\
\hline MK*PDK & - & - & $\begin{array}{c}-0,928 \\
{[-3,311]}\end{array}$ & 0,001 & - & - \\
\hline PE*PDK & - & - & - & - & $\begin{array}{c}-0,072 \\
{[-0,389]}\end{array}$ & 0,698 \\
\hline $\mathrm{R}^{2}$ & 0,856 & & 0,869 & & 0,856 & \\
\hline $\operatorname{Adj}-R^{2}$ & 0,732 & & 0,755 & & 0,733 & \\
\hline F-test & 108,586 & & 90,964 & & 80,896 & \\
\hline F-test (P-value) & 0,000 & & 0,000 & & 0,000 & \\
\hline
\end{tabular}

Sumber: Primary Data (Analysis), 2020.

Note: Value in [ ] is value of $t$ statistical test; $p$-value $<0.05$ identifying significance with confident level of 95\%;

Based upon the above table, the first model (model 1) represents the functional relationship between employee performance with three predictor variables consisting of work motivation, supervision and education level. These three variables have a positive and significant effect on the performance of the employees of the Muhamadiyah University in Aceh. This means that the higher the work motivation, the better the supervision and the higher the education level of the employees, the better their performance will be. Conversely, a decrease in work motivation and supervision as well as a low level of education has an impact on the performance of the university employees.

Model 2 is the MRA to analyze the existence of the level of education in moderating the effect of work motivation on employee performance. As in the table above, the estimated coefficient of work motivation on employee performance is significant with a p-value of 0.000 . Furthermore, the estimated coefficient of moderating variables (the interaction between work motivation and education level) is also significant with a p-value of 0.001 . This means that the level of education moderates the effect of work motivation on employee performance at the Muhamadiyah University Aceh that support the hypothesis $3\left(\mathrm{H}_{3}\right)$. In other words, the level of education obtained by an employee has a significant effect on the causal relationship between their performance and work motivation. This finding is in line with the results of Lee \& Hallak's (2018) research which also proves 
INTERNATIONAL JOURNAL OF ACADEMIC RESEARCH IN BUSINESS AND SOCIAL SCIENCES Vol. 10, No. 9, 2020, E-ISSN: 2222-6990 @ 2020 HRMARS

that a person's educational background moderates the influence of a number of external factors on their performance.

Furthermore, model 3 is a summary of the MRA to examine the existence of the role of the level of education on the relationship between supervision and employee performance. The estimated coefficient of control is significant with a $p$-value of 0.000 . Furthermore, the estimated coefficient of moderating variable (interaction between supervision and education level) is not significant with a p-value of 0.698 . This means that in this case the level of education is not a moderating variable, but only acts as an independent variable. The finding indicates that it does not support the Hypothesis $4\left(\mathrm{H}_{4}\right)$ or $\mathrm{H}_{4}$ is not accepted. This finding contradicts the results of research by Moser \& Galais (2007) which proves that there is a moderating role in the level of education on the effect of supervision on employee performance. This finding is also not in line with the results of studies by Schjoedt \& Sangboon (2015), Sihag \& Rijsdijk (2018) and Remus et al. (2020) also concluded that the level of education affects the impact of supervision on employee performance.

The above analysis indicates that, from 4 hypotheses in this study, there are 3 of them being not rejected, and the rest is not accepted. For more detail, the description of the accepted or rejected hypotheses in this study can be seen as in the following table.

Table 3. Summary of Hypotheses Testing

\begin{tabular}{|c|l|c|}
\hline & \multicolumn{1}{|c|}{ Hypotheses } & Conclusion \\
\hline $\mathbf{H}_{\mathbf{1}}$ & $\begin{array}{l}\text { Work motivation has a positive influence on employee } \\
\text { performance. }\end{array}$ & Not Rejected \\
\hline $\mathbf{H}_{\mathbf{2}}$ & Supervision has a positive influence on employee performance. & Not Rejected \\
\hline $\mathbf{H}_{\mathbf{3}}$ & $\begin{array}{l}\text { The level of education moderates the effect of work motivation } \\
\text { on employee performance. }\end{array}$ & Not Rejected \\
\hline $\mathbf{H}_{\mathbf{4}}$ & $\begin{array}{l}\text { The level of education moderates the effect of supervision on } \\
\text { employee performance. }\end{array}$ & Not Accepted \\
\hline
\end{tabular}

Source: Data Analysis, 2020 
INTERNATIONAL JOURNAL OF ACADEMIC RESEARCH IN BUSINESS AND SOCIAL SCIENCES Vol. 10, No. 9, 2020, E-ISSN: 2222-6990 @ 2020 HRMARS

The final model of this study is as presenting in the following figure:

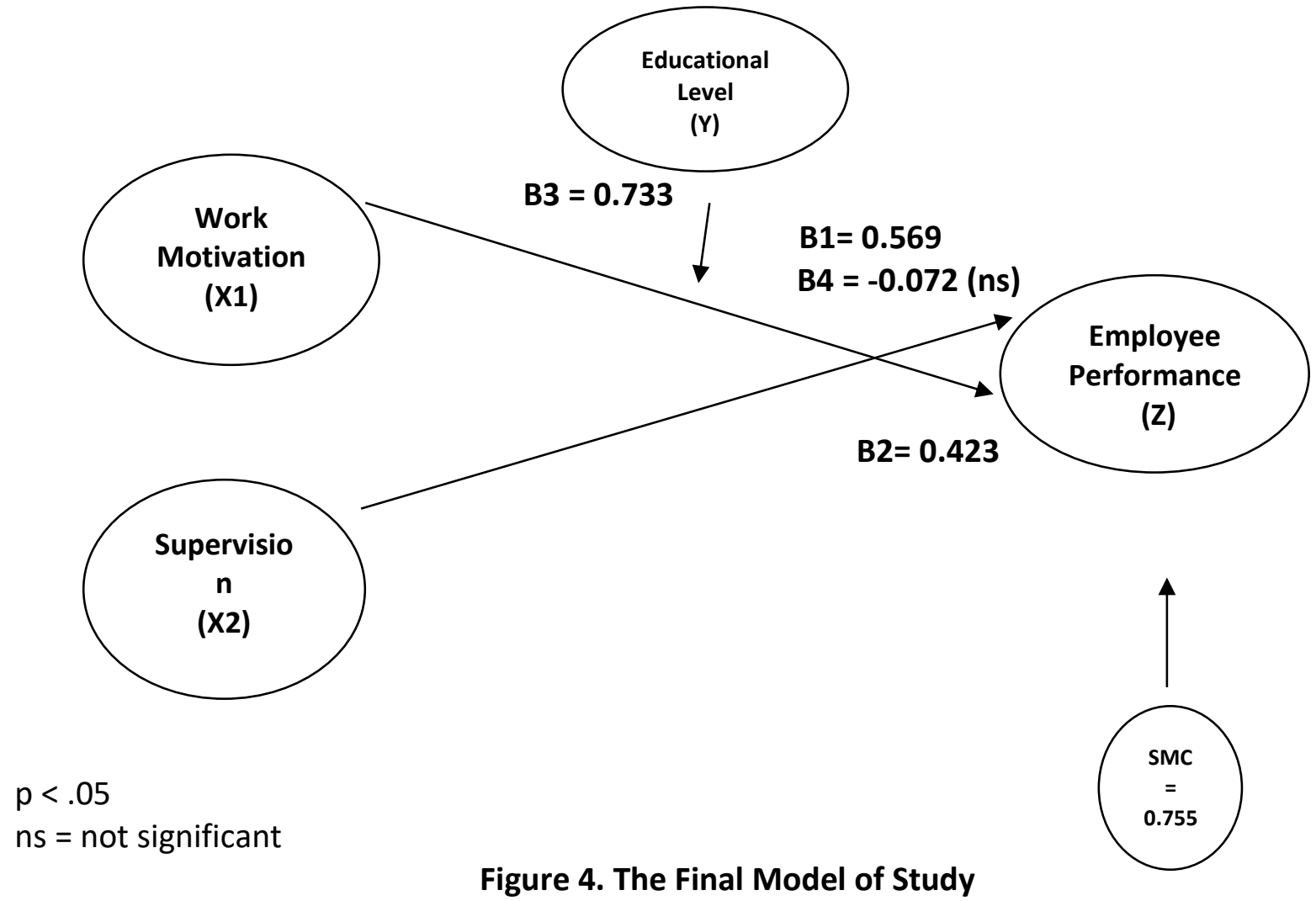

\section{Discussion}

The level of education has a positive and significant effect on the performance of the employees of the Universitas Muhammadiyah Aceh. This indication is shown by the value of the variable estimation coefficient of 0.572 with a p-value of $0.000(<0.05)$. As previously explaination, the education level variables are grouped into two categories, namely undergraduate and postgraduate, so that the variable is in the form of a dummy variable. Interpretation of the relationship between education level and employee performance is associative. Thus, it can be interpreted that the level of education is positively associated with the performance of the college employees. Employees with a higher education level; for example, postgraduate, also perform better than employees with an undergraduate level.

The influence of the level of education on employee performance supports the opinion of $\mathrm{Ng}$ \& Feldman (2009) which states that the level of education has an important contribution in improving employee performance. This finding also strengthens the research results of Awang et al. (2010); González et., Al. (2016); Double et al. (2019) which also proves that there is a positive and significant influence on the level of education on employee performance.

The effect of work motivation and supervision on employee performance can be moderated by the level of education. A number of studies also provide empirical evidence on the role of education level in moderating the influence between variables in human resource management studies (Moser \& Galais, 2007; Capelleras et al. 2016). In connection with the study of the performance of University of Muhammadiyah in Aceh, the analysis of the moderating role of 
education level in the functional relationship between employee performance on the one hand with work motivation and supervision on the other hand uses moderated regression analysis (MRA).

As in the table above, the estimated coefficient of work motivation on employee performance is significant with a $p$-value of 0.000 . Furthermore, the estimated coefficient of moderating variables (the interaction between work motivation and educational level) is also significant with a p-value of 0.001. This means that the level of education moderates the effect of work motivation on employee performance at the University of Muhammadiyah in Aceh. In other words, the level of education obtained by an employee has a significant effect on the causal relationship between their performance and work motivation. This finding is in line with the results of Lee \& Hallak's (2018) research which also proves that a person's educational background moderates the influence of a number of external factors on their performance.

Additionally, the existence of the role of the level of education on the relationship between supervision and employee performance is presented by the estimated coefficient of supervision that it is significant with a $p$-value of 0.000 . Furthermore, the estimated coefficient of moderating variable (interaction between supervision and educational level) is not significant with a $p$-value of 0.698 . This means that, in this case, the level of education is not a moderating variable, but only acts as an independent variable. This finding contradicts the results of research by Moser \& Galais (2007) which proves that there is a moderating role in the level of education on the effect of supervision on employee performance. This finding is also not in line with the results of studies by Schjoedt \& Sangboon (2015); Sihag \& Rijsdijk (2018); Remus et al. (2020) also concluded that the level of education affects the impact of supervision on employee performance.

\section{Conclusion and Recommendation}

Work motivation and supervision have a positive and significant effect on employee performance. Increased work motivation and supervision have an impact on improving employee performance. Conversely, a decrease in work motivation and supervision also significantly reduces employee performance.

The level of education moderates the effect of work motivation on employee performance. That is, the influence of work motivation on an employee's performance is intervened by the employee's education level. The moderating effect caused by the level of education on the relationship between work motivation and employee performance is quasi moderation. Conversely, the level of education does not moderate the effect of supervision on employee performance. The role of education level in the functional relationship between employee performance and supervision is only an independent variable. That is, the existence of the level of education does not interfere with the significant effect of supervision on the performance of the college employees.

Referring to the above research findings, it has confirmed to encourage understanding among academicians and practitioners. In other words, this study has provided a contribution to academic strengthening that there is an existence of educational level as moderator between relationships of work motivation and employee performance.

The leader of the University of Muhammadiyah in Aceh must be able to encourage an increase in employee motivation. Efforts to increase work motivation can be carried out by providing a good understanding and understanding for each employee about the need to improve the quality of work results, the importance of efforts to achieve work targets that have been set and the obligation of an employee to always be responsible for completing their respective workloads. 
INTERNATIONAL JOURNAL OF ACADEMIC RESEARCH IN BUSINESS AND SOCIAL SCIENCES Vol. 10, No. 9, 2020, E-ISSN: 2222-6990 @ 2020 HRMARS

Leaders must also be able to instill a love of employees for the work they do and generate a strong desire in employees so that they can complete all their work properly and measured.

The leader of the University of Muhammadiyah in Aceh must maintain the supervision policy that has been implemented and attached to every employee. Operationally, increased supervision can be carried out through an objective assessment of the work performed. University must form a team of supervisors and evaluators who work objectively and aim to supervise and evaluate the work of their employees. In addition, increasing the clarity of the work performance standards for each employee based upon the duties assigned to them and carries out periodic evaluations of the performance of these tasks to allow corrective and corrective actions when the fault occurs.

As the finding indicates that the effect of work motivation and supervision on employee performance can be moderated by the level of education; therefore, it results an academic contribution that the level of education has an important role as moderating to employee performance.

\section{References}

Ahmed, M., \& Ahmed, A. B. (2014). The Impact of Indirect Compensation on Employee performance: An Overview, Public Policy and Administration Research, 4(6), 27-31.

Ali, N. N. K., \& Tang, S. Y. (2016). Does Multiple Leadership Styles Mediated by Job Satisfaction Influence Better Business Performance? Perception of Mnc Employees in Malaysia, SHS Web of Conferences, 23, 2-16.

As'ad, M. (2013). Psikologi Industri, Liberty, Yogyakarta.

Averus, A., \& Pitono, A. (2018). Pengaruh Pengawasan Terhadap Kinerja Pegawai Dalam Meningkatkan Pelayanan Kesehatan di kota Palu Provinsi Sulawesi Tengah, Sosiohumaniora Jurnal Ilmu-ilmu Sosial dan Humaniora, 20(1), 15 - 21.

Awang, A. H., Ismail, R., \& Noor, M. Z. (2010). Training Impact on Employee'S Job Performance: A Self Evaluation. Economic Research-Ekonomska Istraživanja, 23(4), 78-90. doi:10.1080/1331677x.2010.11517434

Bangun, W. (2012). Manajemen Sumber Daya Manusia. Gelora Aksara Pratama, Jakarta.

Bello, M. S. (2014). Impact of Ethical Leadership on Employee Job Performance, International Journal of Business and Social Science, 3(11) 228-236.

Bernardin, J. H., Russell, J. E. A., (2013), Human Resource Management: An Experiential Approach. Mc Graw-Hill, New York.

Capelleras, J.-L., Contín-Pilart, I., Larraza-Kintana, M., \& Martin-Sanchez, V. (2016). Unemployment and Growth Aspirations: The Moderating Role of Education. Strategic Change, 25(2), 171-185. doi:10.1002/jsc.2054

Cetin, I. (2013). Motivation and Its Impact on Labour Productivity At Hotel Business “A Conceptual Study, International Journal of New Trends in Arts, Sports \& Science Education, 2(1), 70-79.

Chang, Y.-S. (2019). Bonding Ties, Bridging Ties, and Firm Performance: The Moderating Role of Dynamic Capabilities in Networks. Journal of Business-to-Business Marketing, 1-18. doi:10.1080/1051712x.2019.1603395

Chong, N. N., dan Dung, N. V. (2013) Effects of Motivation and Job satisfaction on Employees' Performance at Petrovietnam Nghean Construction Joints Stock Corporation (PVNC), International Journal of Business and Social Science, 4(6), 215-226.

Degago, E. (2014). A Study on Impact of Psychological Empowerment on Employee Performance in 
INTERNATIONAL JOURNAL OF ACADEMIC RESEARCH IN BUSINESS AND SOCIAL SCIENCES Vol. 10, No. 9, 2020, E-ISSN: $2222-6990$ @ 2020 HRMARS

Small and Medium Scale Enterprise Sectors, European Journal of Business and Management, 6(27), 60-71.

Double, K. S., McGrane, J. A., \& Hopfenbeck, T. N. (2019). The Impact of Peer Assessment on Academic Performance: A Meta-analysis of Control Group Studies. Educational Psychology Review. doi:10.1007/s10648-019-09510-3

Fadlallh, A. W. (2014). Impact of Job Satisfaction on Employees Performance an Application on Faculty of Science and Humanity Studies University of Salman Bin Abdul-Aziz-Al Aflaj, International Journal of Innovation and Research in Educational Sciences, 2(1), 26-31.

Fathoni, A. (2016). Organisasi dan Manajemen Sumber Daya Manusia, Rineka Cipta, Jakarta.

González, F., Sánchez, S. M., \& López-Guzmán, T. (2016). The Effect of Educational Level on Job Satisfaction and Organizational Commitment: A Case Study in Hospitality. International Journal of Hospitality \& Tourism Administration, 17(3), 243-259. doi:10.1080/15256480.2016.1183547

Hair, J. F., Anderson, R., E., Tatham, R. L., \& Black, W. C. (2013), Multivariate data analysis (7 ${ }^{\text {th }}$ ed.). Prentice Hall, Pearson Educational International.

Hasbullah, S. (2013). Dasar-Dasar Ilmu Pendidikan, Rajagravindo Persada, Jakarta.

Hasibuan, M. (2016). Dasar-dasar, Pengertian, dan Masalah Dalam Manajemen. Bumi aksara, Jakarta.

Hasibuan, M. S. P (2012). Manajemen Sumber Daya Manusia. Bumi Aksara, Bandung.

Lee, C., \& Hallak, R. (2018). Investigating the moderating role of education on a structural model of restaurant performance using multi-group PLS-SEM analysis. Journal of Business Research, 88, 298-305. doi:10.1016/j.jbusres.2017.12.004

Luthans, Fred. (2015). Organizational Behavior (7th ed.). McGraw-Hill, Inc.

Mangkunegara, A. P. (2003). Perencanaan dan Pengembangan Sumber Daya Manusia, Refika Aditama, Bandung.

Mangkuprawira, S. (2013). Manajemen Sumber Daya Manusia Strategik, Cetakan Kedua, Ghalia Indonesia, Jakarta.

Mohiuddin, Z. A. (2017). Influence of Leadership Style on Employees performance: Evidence from Literatures, Journal of Marketing and Management, 8(1), 18-30.

Moser, K., \& Galais, N. (2007). Self-Monitoring and Job Performance: The moderating role of tenure. International Journal of Selection and Assessment, 15(1), 83-93. doi:10.1111/j.14682389.2007.00370.x

Muogbo, U. S. (2013). The Influence of Motivation on Employees' Performance: A Study of Some Selected Firms in Anambra State, International Journal of Arts and Humanities, 2(3), 134-151.

Ng, T. W. H., \& Feldman, D. C. (2009). How broadly does education contribute to job performance? Personnel Psychology, 62(1), 89-134. doi:10.1111/j.1744-6570.2008.01130.x

Notoatmojo, S. (2013) Pengembangan Sumber Daya Manusia. Rineka Cipta, Jakarta.

Omollo, A., \& Oloko. (2015). Effect of motivation on employee performance of commercial banks in Kenya: A case study of Kenya Commercial Bank in Migori County Pamela, International Journal of Human Resource Studies, 5(2), 87-103.

Orpen, C. (1994). Interactive Effects of Work Motivation and Personal Control on Employee Job Performance and Satisfaction. The Journal of Social Psychology, 134(6), 855-856. doi:10.1080/00224545.1994.9923021

Remus, U., Wiener, M., Saunders, C., \& Mähring, M. (2020). The impact of control styles and control modes on individual-level outcomes: a first test of the integrated IS project control theory. 
INTERNATIONAL JOURNAL OF ACADEMIC RESEARCH IN BUSINESS AND SOCIAL SCIENCES Vol. 10, No. 9, 2020, E-ISSN: 2222-6990 @ 2020 HRMARS

European Journal of Information Systems, 1-19. doi:10.1080/0960085x.2020.1718008

Renah, A., \& Setyadi, D. (2014). The Influence of Organizational Culture, Working Environment and Educational Training on Motivation and Performance of Government Employees at West Kutai Regency East Kalimanatan, European Journal of Business and Management, 6(30), 182-191.

Robbin, S. P. (2012) Perilaku Organisasi: Konsep Kontroversi, Aplikasi, Edisi Bahasa Indonesia, Jilid 2, Prenhallindo, Jakarta.

Sargent, L. D., \& Terry, D. J. (1998). The effects of work control and jobdemands on employee adjustment and work performance. Journal of Occupational and Organizational Psychology, 71, 219-236.

Schjoedt, L., \& Sangboon, K. (2015). Control Variables: Problematic Issues and Best Practices. The Palgrave Handbook of Research Design in Business and Management, 239-261. doi:10.1057/9781137484956_15

Segal, J. (2010). Melejitkan Kepekaan Emosional, Penerjemah Ary Nilandari, Kaifah, Bandung.

Shahzadi, I., Javed, A., Pirzada, S. S., Nasreen, S., \& Khanam, F. (2014). Impact of Employee Motivation on Employee Performance, European Journal of Business and Management, 6(23), 159-166.

Siagian, S. P. (2016). Filsafat Administrasi. Edisi Revisi. Bumi Aksara, Jakarta.

Sihag, V., \& Rijsdijk, S. A. (2018). Organizational Controls and Performance Outcomes: A MetaAnalytic Assessment and Extension. Journal of Management Studies. doi:10.1111/joms.12342

Situmeang, R. R. (2017). Pengaruh pengawasan dan pengalaman kerja terhadap kinerja karyawan pada PT. Mitra Karya Anugrah, Asian Journal of Innovation and Entrepreneurship, 2(2), 148-160.

Srivastava, A. K (2008) Effect of Perceived Work Environment on Employees' Job Behaviour and Organizational Effectiveness, Journal of the Indian Academy of Applied Psychology, 34(1), 47-55.

Syamsidar, E., \& Hasyim, S. B. (2018). Pengaruh pengawasan terhadap kinerja pegawai di kantor sub unit rumah perlindungan sosial asuhan anak (RPSAA) Cisurupan - Garut, Jurnal Pembangunan dan Kebijakan Publik, 9(1), 12-20.

Uddin, M. J., Luva, R. H., \& Hossian, S. M. M. (2013). Impact of Organizational Culture on Employee Performance and Productivity: A Case Study of Telecommunication Sector in Bangladesh, International Journal of Business and Management, 8(2), 63-77.

Uno, H. (2007). Teori Motivasi dan Pengukurannya: Analisis Bidang Pendidikan, Bumi Aksara, Jakarta. 